\title{
Habitat-Based Breeding Strategies of Female Hoplobatrachus occipitalis (Anura: Dicroglossidae) from Daloa Department, Midwest of Côte d'Ivoire
}

\author{
ALIKO N'guessan Gustave ${ }^{1 *}$, ASSEMIAN N'guessan Emmanuel ${ }^{1}$, BOUSSOU Koffi Charles ${ }^{1}$, \\ KEITA Gaoussou ${ }^{1}$, KONAN Koffi Félix ${ }^{1}$ \\ ${ }^{I}$ Department of Biodiversity and Sustainable Management of Ecosystems, Faculty of Environment, Jean \\ Lorougnon Guédé University, POB 150 Daloa, Côte d'Ivoire
}

*Corresponding Author: ALIKO N'guessan Gustave, Department of Biodiversity and Sustainable Management of Ecosystems, Faculty of Environment, Jean Lorougnon Guédé University, POB 150 Daloa, Côte d'Ivoire

\begin{abstract}
Habitat impact on reproductive biology of female Hoplobatrachus occipitalis had been studied in wetlands of Daloa Department. Two sites were sampled; one located in urban areas (Fatiga) and the other in rural areas (Zaliohouan). Four night and day sampling surveys were conducted from June to July 2017. Specimens of Hoplobatrachus occipitalis were captured and females dissected to determine gonado-somatic index (GSI), fecundity and egg diameter. Sex ratios were largely in favor of females in both populations (f: $m=1: 0.40$ at Fatiga and $f: m=1: 0.68$ at Zaliohouan). Mean female size did not vary significantly between sampled sites $(S V L=92.93 \pm 8.46 \mathrm{~mm}$ and $S V L=97.67 \pm 8.53 \mathrm{~mm}$ respectively at Fatiga and Zaliohouan). Reproductive parameters varied little between populations. However, the highest values were obtained at the rural site. Averages of GSI were 8.81 and $10.94 \%$ in Fatiga and Zaliohouan females, respectively. Concerning absolute fecundity, average of 1872.47 \pm 499.87 eggs was obtained in females at Fatiga against $2467.13 \pm 1314.65$ eggs at Zaliohouan. Mean oocyte diameter was $1.12 \pm 0.29 \mathrm{~mm}$ at Fatiga against $1.20 \pm 0.22 \mathrm{~mm}$ at Zaliohouan. There was positive correlation between female size and fecundity. But negative correlation was observed between female size and oocyte diameter. Low spatial variability in parameters indicated adaptation capacity in reproduction of Hoplobatrachus occipitalis.
\end{abstract}

Keywords: Anura, Hoplobatrachus occipitalis, Reproductive parameters, Habitat impact, Côte d'Ivoire.

\section{INTRODUCTION}

Hoplobatrachus occipitalis is a common and widespread West African frog occurring in both savanna and disturbed forest habitats. It also inhabits diverse water habitats including small, large, fast flowing, stagnant, temporary and or permanent water bodies [1]. This frog species is native to Nigeria and in view of the wide distribution; it is tolerant to a wide variety of habitats [2]. The presumed large population of $H$. occipitalis led to its categorization as "Least Concern" by the International Union for Conservation of Nature (IUCN) probably because it is unlikely to be declining fast enough to qualify for listing in a more threatened category. Its population however, is on the decline [3].

This frog species is consumed by African populations for whom it represents an important source of animal protein. In Nigeria, H. occipitalis was identified as the most commercialized species [4]. In the region of Kisangani (Democratic Republic of Congo), the species was much appreciated and exploited for human consumption [5]. In Côte d'Ivoire, consumption of frogs concerns particularly some people in the west of the country. In the Department of Daloa, the humid climate favors the existence of many wetlands including ponds and shallows. These ecosystems have favored proliferation of amphibian populations in both urban and rural areas. Among the frogs encountered in this Department, Hoplobatracus occipiltalis is one of the most abundant and most consumed. This species is therefore subject to strong human predation in order to satisfy the demand for food consumption. Faced with the threat of overexploitation of the natural stocks of this frog, it is necessary to consider an artificial production of the species. In this perspective, Knowledge of reproductive biology of the species in its natural habitat is essential. 
Anuran reproductive biology has interested researchers for decades. Detailed research has focused on reproductive endocrinology (e.g. [6,7]), mating systems [8,9], communication [10, 11], parental care $[12,13]$, reproductive modes [14], and larval biology [15]. But understanding of the ecology and evolution of anuran reproduction is far from complete, as suggested by observations of peculiar behaviour and natural history in some species [16].

The purpose of this study was to assess the impact of habitat on the reproductive biology of the female frog Hoplobatrachus occipitalis in wetlands of Daloa Department.

\section{Materials AND Methods}

\subsection{Study Sites}

An urban site and a rural site were selected in Daloa Department of Côte d'Ivoire (Figure 1). The urban site is located in Fatiga district of Daloa city $\left(6^{\circ} 52^{\prime} 30^{\prime \prime} \mathrm{N}-7^{\circ} 34^{\prime} 30^{\prime \prime} \mathrm{W}\right)$. This site is a shallow used for rice growing. The rural site is composed of ponds located in the surrounding vegetation of Zaliohouan village $\left(6^{\circ} 47^{\prime} 29^{\prime}\right.$ ' $\mathrm{N}-7^{\circ} 46^{\prime} 5^{\prime}$ 'W). The local climate is tropical wet, type of transition. This climate is characterized by two seasons: a rainy season from April to September and a dry season from October to March. Annual rains increased from $1868.5 \mathrm{~mm}$ in 1968 to $1120.4 \mathrm{~mm}$ in 2005 [17]. Some physico-chemical parameters of the study sites are presented in table 1.

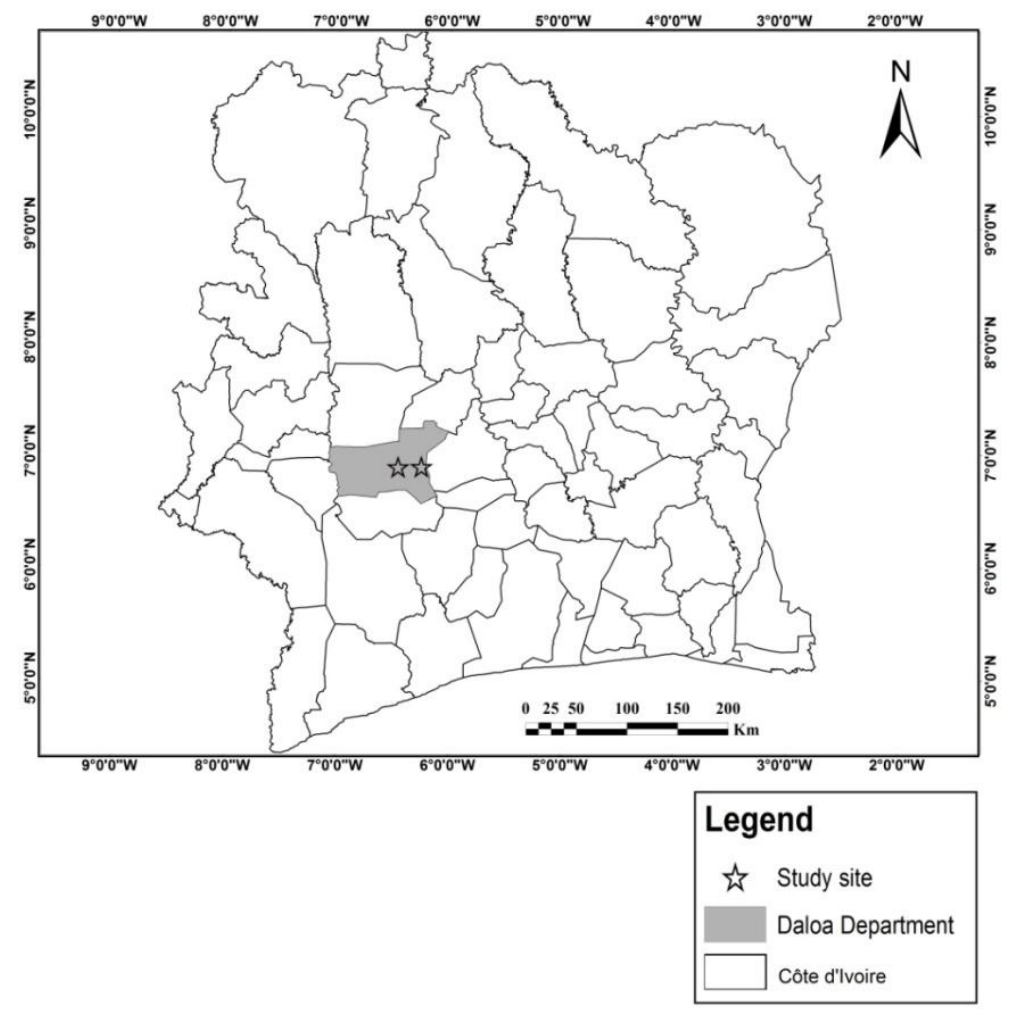

Figure1. Location of study sites

Table1. Some physico-chemical parameters of study sites in Daloa Department of Côte d'Tvoire

\begin{tabular}{|l|l|l|}
\hline Parameters & Fatiga site & Zaliohouan site \\
\hline Water temperature $\left({ }^{\circ} \mathrm{C}\right)$ & $23.20-23.40$ & $23.05-24.20$ \\
\hline pH of waters & $7.17-7.27$ & $5.99-7.09$ \\
\hline Water conductivity $(\mu \mathrm{S} / \mathrm{cm})$ & $305.85-378.90$ & $137.40-261.00$ \\
\hline Humidity of the air $(\%)$ & $72.23-74.60$ & $66.90-70.40$ \\
\hline
\end{tabular}

\subsection{Data Sampling}

Frog fauna was sampled weekly from June to July 2017. Specimens were collected using visual and auditory search according to the standard techniques of [18] and [19]. Surveys were conducted at night and during daytime. Captured individuals had been identified using keys and descriptions established by [20] and [19]. Concerning specimens of Hoplobatrachus occipitalis, males were distinguished from females by their vocal sac. For each female, total weight and snout-vent length 
(SVL) were recorded. Then, the female had a longitudinal incision made along the abdominal surface, whereby the ovaries were removed and weighed on a precision scale $(0.01 \mathrm{~g})$. Body mass $(\mathrm{BM})$ of the female was also recorded after dissection. Mature eggs of ovaries were counted and individual egg diameter was measured to the nearest $0.1 \mathrm{~mm}$ with an ocular micrometer in a Zeiss stereomicroscope.

\subsection{Data Analysis}

Individual lengths (SVL) of females were used to obtain size frequency distribution and mean size of females per study site. Frequency distribution of egg diameters was also plotted per site and mean values were compared. Sex ratio of each population was determined as number of males for one female [21]. The Chi-square test was used to assess if sex ratio (f:m) differed significantly from the expected ratio $1: 1$.

We determined female gonado-somatic index $(G S I)$ as follows:

$G S I=G M \times 100 / B M$ where $G M$ and $B M$ represent ovary mass and body mass respectively [22].

Absolute fecundity $(\mathrm{Fa})$ was estimated by gravimetric method through sub-sampling [23]. Relative fecundity in length $\left(F_{L}\right)$ and relative fecundity in weight $\left(F_{W}\right)$ were assessed respectively as number of eggs per unit of total length (SVL) (Eggs/mm) and number of eggs per unit of body weight $(\mathrm{Eggs} / \mathrm{g})$ [23]. Fecundity and egg diameter were correlated to female size (SVL) using linear regression analysis [24].

Differences between mean values of study sites were assessed using the $t$-test after checking that data distribution is normal. Statistical analyzes were performed with STATISTICA 7.1 software. A significance level of $p=0.05$ was used.

\section{RESUltS}

\subsection{Sex Ratio in Hoplobatrachus occipitalis Populations from Study Sites}

At the site of Fatiga, 28 males and 57 females were sampled, representing a sex ratio f:m of 1:0.40. At the site of Zaliohouan, samples were composed of 62 males and 91 females, indicating a sex ratio f:m of 1:0.68. Both sex ratios were significantly female-biased ratios $\left(\chi^{2}=9.89 ; p<0.05\right.$ for population of Fatiga and $\chi^{2}=5.5 ; \mathrm{p}<0.05$ for population of Zaliohouan).

\subsection{Females' Size}

Size of female Hoplobatrachus occipitalis ranged from 80 to $110 \mathrm{~mm} \mathrm{SVL}$ at Fatiga site (N=15) and from 84 to $116 \mathrm{~mm} \mathrm{SVL}$ at Zaliohouan site $(\mathrm{N}=15)$. Size frequency distribution indicated one mode at 90-95 mm SVL for both populations (Figure 2). Mean size was 92.93 \pm 8.46 and $97.67 \pm 8.53 \mathrm{~mm} \mathrm{SVL}$ respectively for females of Fatiga and Zaliohouan; and did not varied significantly from one study site to another ( $t$-test: $\mathrm{t}=-1.53 ; \mathrm{p}>0.05$ ) (Figure 3 ).
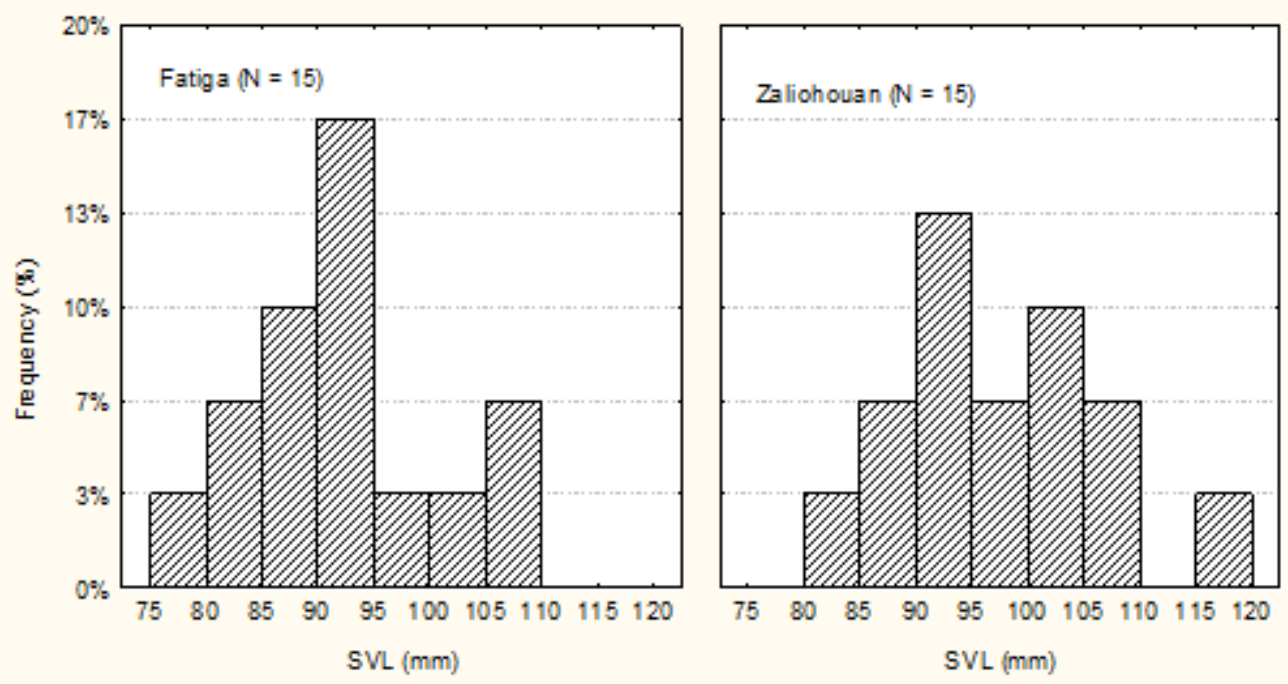

Figure2. Size (SVL) frequency distribution of female Hoplobatrachus occipitalis from Fatiga and Zaliohouan in Daloa Department 


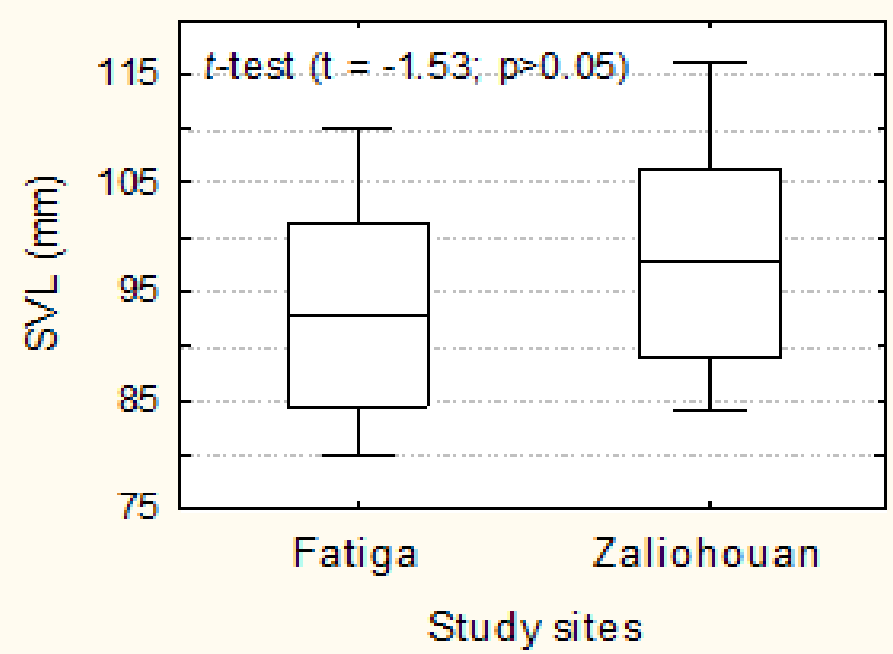

Figure3. Spatial variability in size (SVL) of female Hoplobatrachus occipitalis from Fatiga and Zaliohouan in Daloa Department

\subsection{Gonado-Somatic Index}

For females from Fatiga, gonado-somatic index varied from 2.89 to $21.07 \%$ with average of $9.54 \pm 5.05 \%$. Concerning females from Zaliohouan, the lowest GSI was $5.54 \%$ while the highest was $24.25 \%$, and the average was $11.59 \pm 5.25 \%$. GSI of these two populations of females Hoplobatrachus occipitalis were not significantly different $(t$-test: $\mathrm{t}=-1.09 ; \mathrm{p}>0.05)$ (Figure 4$)$. The smallest mature female measured $80 \mathrm{~mm} \mathrm{SVL}$ at Fatiga and $84 \mathrm{~mm} \mathrm{SVL}$ at Zaliohouan.

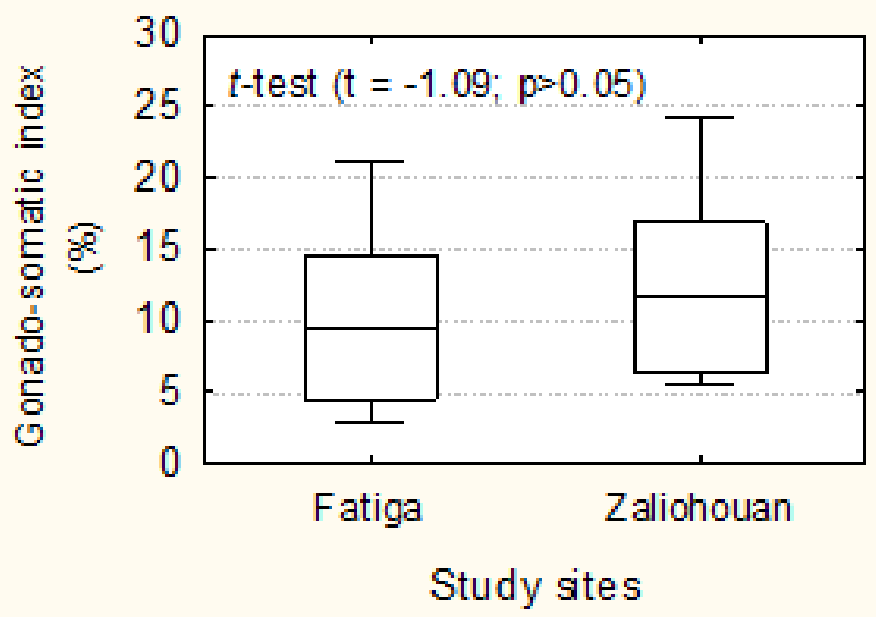

Figure4. Spatial variability in gonado-somatic index of female Hoplobatrachus occipitalis from Fatiga and Zaliohouan in Daloa Department

\subsection{Absolute Fecundity and Relative Fecundity}

Absolute fecundity $(\mathrm{Fa}$ ) varied from 978 to 2935 eggs for females from Fatiga with average of $1872.47 \pm 499.87$ eggs. At Zaliohouan, the lowest $F a$ was 1011 eggs while the highest was 5267 eggs, and an average of $2467.13 \pm 1314.65$ eggs was recorded. There was no significant difference between fecundity of the two populations of females ( $t$-test: $\mathrm{t}=-1.64 ; \mathrm{p}>0.05)$ (Table 2 ).

Mean values of relative fecundity in length $\left(F_{L}\right)$ and relative fecundity in weight $\left(F_{W}\right)$ were higher for females from Zaliohaouan $\left(F_{L}=25.19 \pm 13.04\right.$ eggs $/ \mathrm{mm}$, range: $12.04-48.77$ eggs $/ \mathrm{mm} ; F_{W}=37.50 \pm$ 21.07 eggs/g, range: $13.37-73.94$ eggs/g) in comparison to females from Fatiga $\left(F_{L}=20.14 \pm 4.76\right.$ eggs $/ \mathrm{mm}$, range: $9.50-27.69 \mathrm{eggs} / \mathrm{mm} ; F_{W}=33.24 \pm 9.65 \mathrm{eggs} / \mathrm{g}$, range: $15.01-52.74$ eggs $\left./ \mathrm{g}\right)$. However, no significant difference was observed between these values (Table 2). 
Habitat-Based Breeding Strategies of Female Hoplobatrachus occipitalis (Anura: Dicroglossidae) from Daloa Department, Midwest of Côte d'Ivoire

Table2. Descriptive statistics of absolute fecundity $(F a)$, relative fecundity in length $\left(F_{L}\right)$ and relative fecundity in weight $\left(F_{W}\right)$ of female Hoplobatrachus occipitalis from Fatiga and Zaliohaouan in Daloa Department

\begin{tabular}{|c|c|c|c|c|c|c|}
\hline & \multicolumn{2}{|l|}{$\begin{array}{l}\text { Fatiga site } \\
(N=15)\end{array}$} & \multicolumn{2}{|c|}{$\begin{array}{l}\text { Zaliohouan site } \\
(\mathbf{N}=\mathbf{1 5})\end{array}$} & \multicolumn{2}{|l|}{$t$-test } \\
\hline Fecundity & Min - Max & $\begin{array}{l}\text { Mean } \\
\pm \text { SD }\end{array}$ & Min - Max & $\begin{array}{l}\text { Mean } \\
\pm \text { SD }\end{array}$ & $\mathrm{t}$ & $\mathrm{p}$ \\
\hline$F a($ Egg/clutch $)$ & $978-2935$ & $\begin{array}{l}1872.47 \\
\pm 499.87\end{array}$ & $1011-5267$ & $\begin{array}{l}2467.13 \\
\pm 1314.65\end{array}$ & -1.637 & 0.113 \\
\hline$F_{L}(\mathrm{Egg} / \mathrm{mm})$ & $9.50-27.69$ & $\begin{array}{l}20.14 \\
\pm 4.76 \\
\end{array}$ & $12.04-48.77$ & $\begin{array}{l}25.19 \\
\pm 13.04\end{array}$ & -1.408 & 0.170 \\
\hline$F_{W}(\mathrm{Egg} / \mathrm{g})$ & $15.01-52.74$ & $\begin{array}{l}33.24 \\
\pm 9.65 \\
\end{array}$ & $13.37-73.94$ & $\begin{array}{l}37.50 \\
\pm 21.07\end{array}$ & -0.711 & 0.483 \\
\hline
\end{tabular}

\subsection{Eggs Diameter}

For females sampled at Fatiga, egg diameter ranged from 0.48 to $1.53 \mathrm{~mm}$ and exhibited an unimodal pattern; with mode at: 1.0-1.1 mm. Females from Zaliohouan presented egg diameter ranging from 0.88 to $1.68 \mathrm{~mm}$ and showed also unimodal pattern with mode at: 1.1-1.2 mm (Figure 5). Mean egg diameter did not differed significantly ( $t$-test: $\mathrm{t}=0.84 ; \mathrm{p}>0.05)$ between the two populations of females (Mean diameter of $1.12 \pm 0.29 \mathrm{~mm}$ for females at Fatiga and mean diameter of $1.20 \pm 0.22$ for females at Zaliohouan) (Figure 6).
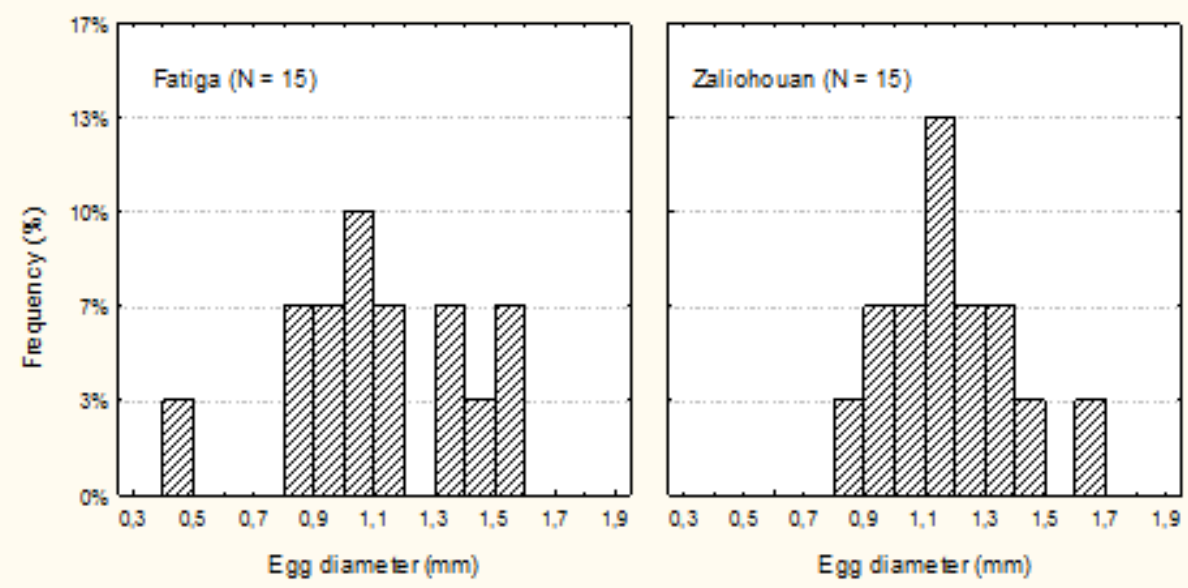

Figure5. Egg diameter frequency distribution of female Hoplobatrachus occipitalis from Fatiga and Zaliohouan in Daloa Department.

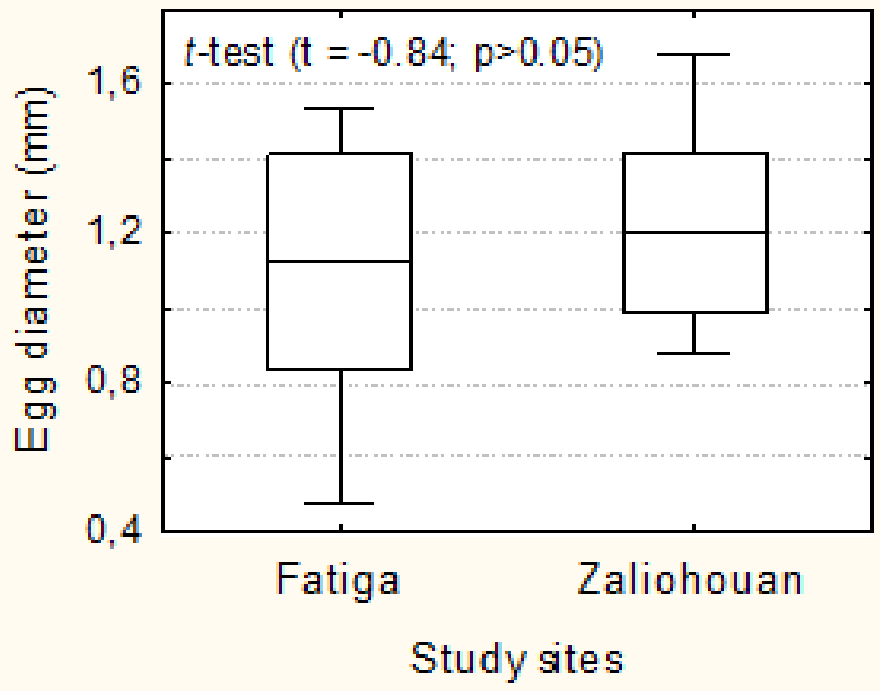

Figure6. Spatial variability in egg diameter of female Hoplobatrachus occipitalis from Fatiga and Zaliohouan in Daloa Department 
Habitat-Based Breeding Strategies of Female Hoplobatrachus occipitalis (Anura: Dicroglossidae) from Daloa Department, Midwest of Côte d'Ivoire

\subsection{SVL-Fecundity and SVL-Egg Diameter Relationships}

For females from Fatiga and Zaliohouan, there was positive correlation between absolute fecundity and SVL (Figure 7), but correlation was not significant neither at Fatiga nor at Zaliohouan ( $\mathrm{r}=0.249$; $\mathrm{p}>0.05$ for females at Fatiga; $r=0.243 ; \mathrm{p}>0.05$ for females at Zaliohouan).

Relationship between egg diameter and SVL indicated negative, but not significant, correlation for both populations of females $(r=-0.200 ; p>0.05$ for females at Fatiga; $r=-0.019 ; p>0.05$ for females at Zaliohouan) (Figure 8).
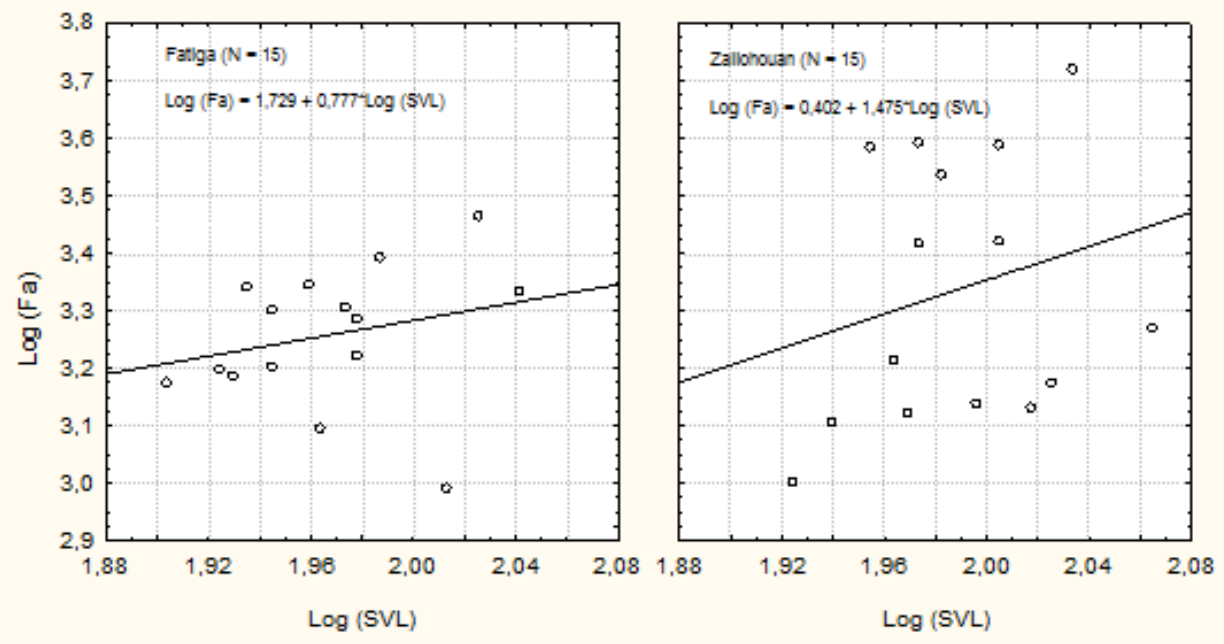

Figure7. Regression between female size (SVL) and absolute fecundity $(\mathrm{Fa})$ in Hoplobatrachus occipitalis from Fatiga and Zaliohouan in Daloa Department

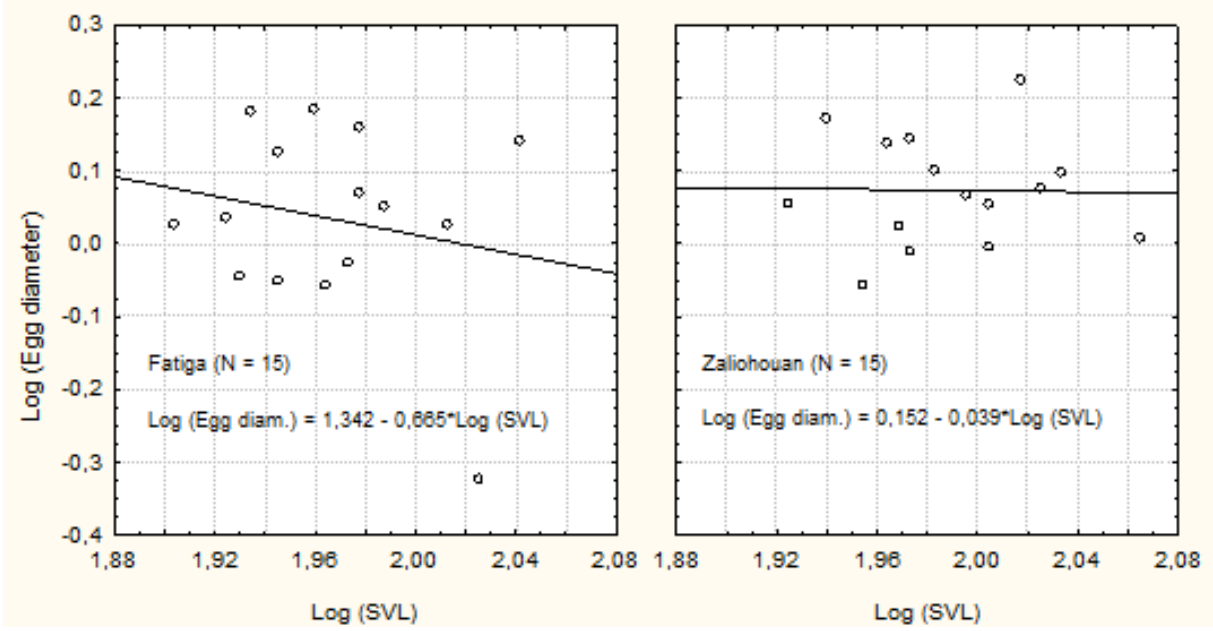

Figure8. Regression between female size (SVL) and egg diameter in Hoplobatrachus occipitalis from Fatiga and Zaliohouan in Daloa Department

\section{DISCUSSIONS}

Sex ratios recorded in both study sites differed significantly from the equilibrium sex ratio ( 1 female for 1 male). The high abundance of females relative to males could be due to high predation of riparian populations on male individuals. Indeed, males are much more identifiable and captured because of the songs they emit. This finding was different from those of [25] obtained in Banco National Park, where males were predominant in the population of Hoplobatrachus occipitalis. As Banco Forest is a protected area, the predominance of males could be explained by the almost nonexistence of human predation. Female size indicated low spatial variability between the two sampled sites. This result could be explained by a wide availability of food resources in the two study sites. Otherwise, maximum sizes recorded in this study $(\mathrm{SVL}=110 \mathrm{~mm}$ at Fatiga and $\mathrm{SVL}=116 \mathrm{~mm}$ at Zaliohouan) were larger than maximum size of females sampled in Comoé National Park by [1] $(\mathrm{SVL}=65 \mathrm{~mm})$. 
Concerning gonado-somatic index and fecundity, highest values were obtained at the rural site of Zaliohouan. The low values recorded at Fatiga would be a consequence of the relatively high degree of anthropization in this site. Amphibians are very sensitive to any changes in their habitat because of their mid-aquatic and mid-terrestrial lifestyle. The disruptive factors are diverse: habitat destruction, pollution, climate change, etc [26, 27]. The gonado-somatic index reported by [25] for female Hoplobatrachus occipitalis in Banco National Park (GSI=2.6-11.5\%) are within the range of GSI values of females analyzed in this study (GSI=1.18-24.25\%). However, mean absolute fecundities recorded in this study were lower than that reported by [25] who obtained an average absolute fecundity of 3286 oocytes. In addition, the size of the smallest mature female observed in this study ( $\mathrm{SVL}=80$ and $84 \mathrm{~mm}$ respectively at Fatiga and Zaliohouan) was smaller than that of the smallest mature female observed by [25] in Banco National Park (SVL=122 mm).

Egg diameters of females did not differ significantly between the two studied sites. This finding may reflect the ability of Hoplobatrachus occipitalis to cope with the adverse effects of anthropization of its habitat. Indeed, this frog is presented as characteristic species of degraded habitats [28]. Egg diameters observed in this study (Egg diameter=0.5-1.7 mm) were close to those obtained by [29] in Outamba-Kilimi Region of Sierra Leone (Egg diameter=1.6-1.8 mm). But, our values remained much lower than those reported by [30], [25] and [31]. Mean oocyte diameters of 2.7 and $3 \mathrm{~mm}$ were recorded respectively by [25] and [30]. Oocyte diameters obtained in females of Hoplobatrachus occipitalis by [31] ranged from 2.9 to $3.7 \mathrm{~mm}$.

Our results showed positive correlation between absolute fecundity and SVL and corroborated those of [32] who stated that female size is positively correlated with fecundity in many species of frogs (e.g. $[33,34])$. But, this author added that egg production may exhibit considerable variation among females in a single population (e.g. [33]). Besides size, other factors may influence female fecundity, as environmental conditions and female nutritional state (e.g. [33]). However, low negative correlation was observed between female size and egg diameter. This finding differed from [32] results which indicated positive and significant correlations in female frogs of the Pantanal, Brazil (e.g. Chiasmocleis mehelyi, Hyla nana, Leptodactylus chaquensis, Lysapsus limellus, Phrynohyas venulosa, Pseudis paradoxa and Scinax acuminatus). According to [32], this fact may probably be related with many different selective pressures leading to differences in egg sizes.

\section{Conclusions}

This study focused on spatial variability of some reproductive parameters of the edible frog Hoplobatrachus occipitalis in two different sites of Daloa Department. Female's size varied little from one site to another. Sex ratios in both populations were largely in favor of females. Analyzed reproductive parameters did not differ significantly between the two populations. However, the highest values were obtained at the rural site. Correlation was positive between female size and fecundity. But low negative correlation was observed between female size and oocyte diameter. The low spatial variability in these reproductive parameters would indicate an adaptive capacity in the species' reproduction. This adaptability could be a major asset for the renewal of the natural stock. Finally, given the socio-economic importance of this edible species, it would be interesting to consider artificial reproduction trials in order to control its breeding.

\section{ACKNOWLEDGMENT}

Authors are grateful to Dr. Tra Bi C. Sylvain for his assistance in the statistical processing of data in this study.

\section{REFERENCES}

[1] Rödel M.O., Herpetofauna of West Africa Vol. I Amphibians of the West African Savanna. Edition Chimaira, 333p (2000a).

[2] Frost D.R., Amphibian Species of the World: an Online Reference. Version 5.6 (9 January 2013). Electronic Database. American Museum of Natural History, New York, USA. Available at: http://research. amnh.org/herpetology/amphibia/index.html. (2013).

[3] IUCN, IUCN SSC Amphibian Specialist Group. 2014. Hoplobatrachus occipitalis. The IUCN Red List of Threatened Species 2014: e.T58299A18361413. http://dx.doi.org/10.2305/IUCN.UK.2014-1.RLTS.T58 299A18361413.en. Downloaded on 18 May 2018 (2014). 
[4] Onadeko A.B., Egonmwan R.I. and Saliu J.K., "Edible amphibian species: local knowledge of their consumption in southwest Nigeria and their nutritional value". West African journal of applied ecology, 19(1): 67-76 (2011).

[5] Mazyambo A., Inventaire des Ranidae (Amphibia) comestibles de Kisanagni, mém. Inédit Fac. Sc. UNIKIS, 36p (1981).

[6] Fernández S.N. and Ramos I., Reproductive biology and phylogeny of Anura. Enfield (NH): Science Publishers Inc. Chapter 4, Endocrinology of reproduction; 73 - 117 (2003).

[7] Rastogi R.K., Iela L., di Meglio M, Di Fiore M.M., D’Aniello B., Pinelli C. and Fiorentino M., Amphibian biology, volume 6: endochrynology. New South Wales: Surrey Beatty and Sons. Chapter 2, Hormonal regulation of reproductive cycles in amphibians; 2045 - 2177 (2005).

[8] Halliday T. and Tejedo M., Amphibian biology, volume 2: social behaviour. New South Wales: Surrey Beatty and Sons. Chapter 1, Intrasexual selection and alternative mating behaviour; 419 - 468 (1995).

[9] Sullivan B.K., Ryan M.J. and Verrell P.A., Amphibian biology, volume 2: social behaviour. New South Wales: Surrey Beatty and Sons. Chapter 2, Female choice and mating system structure; 469 - 517 (1995).

[10] Ryan M.J., Anuran communication. Washington (DC): Smithsonian Institution Press. (2001).

[11] Gerhardt H.C. and Huber F., Acoustic communication in insects and anurans: common problems and diverse solutions. Chicago (IL): University of Chicago Press (2002).

[12] Crump M.L., Amphibian biology, volume 2: social behaviour. New South Wales: Surrey Beatty and Sons. Chapter 3, Parental care; 518 - 567 (1995).

[13] Lehtinen R.M. and Nussbaum R.A., Reproductive biology and phylogeny of Anura. Enfield (NH): Science Publishers Inc. Chapter 8, Parental care: a phylogenetic perspective; 343 - 386 (2003).

[14] Gomez-Mestre I., Pyron R.A. and Wiens J.J., Phylogenetic analyses reveal unexpected patterns in the evolution of reproductive modes in frogs. Evolution. 66:3687 - 3700. (2012).

[15] McDiarmid R.W. and Altig R., Tadpoles: the biology of anuran larvae. Chicago (IL): University of Chicago Press (1999).

[16] Wells K.D., The ecology and behavior of amphibians. Chicago (IL): The University of Chicago Press (2007).

[17] Ligban R., Goné L.D., Kamagaté B., Saley M.B. and Biémi J., Processus hydrogéochimique et origine des sources naturels dans le degré carré de Daloa, Int. J. Biol. Chem. Sci. 3(1): 38-47 (2009).

[18] Crump M.L. and Jr. Scott N.J., Visual encounter surveys. In: Heyer, W.R., M.A. Donnelly, R.W. McDiarmid, L.C. Hayek, M.S. Foster (Eds.). Measuring and monitoring biological diversity: standard methods for amphibians. Smithsonian Institution Press, Washington (1994).

[19] Rödel M.O. and Ernst R., The amphibians of Marahoué and Mont Péko National Parks, Ivory Coast. Herpetozoa: 23-39 (2003).

[20] Rödel M.O. and Branch W.R., Herpetological survey of Haute Dodo and Cavally forests, western Ivory Coast, Part I: Amphibians. Salamandra, 38 (4): 245-268 (2002).

[21] Xie J.Y., Xia Y., Yan Y., Liang W.T. and Ren C., Reproductive cycle of Triplophysa stenura (Herzenstein, 1888) (Balitoridae: Nemacheilinae) from the Yarlung Tsangpo River in the Tibetan Plateau, China. J. Appl. Ichthyol., 33: 37-41 (2017).

[22] Kaefer I.L., Boelter R.A. and Cechin S.Z., Reproductive biology of the invasive bullfrog Lithobates catesbeianus in southern Brazil. Ann. Zool. Fennici 44: 435-44 (2007).

[23] Yin M.C., The ecology of fishes. China Agriculture Press, Beijing: 105-131 (1993).

[24] Zar J.H., Biostatistical Analysis. 4th Edition. Prentice-Hall, Englewood Cliffs, New Jersey, 662p (1999).

[25] Tohé B., Assemian N.E. and Kouamé N.G., Reproduction of African Tigrine Frog Hoplobatrachus occipitalis in Banco National Park (Ivory Coast). International Journal of Science and Research, 5 (1): 577-581 (2016).

[26] Blaustein R. and Kiesecker J.M., Complexity in conservation: lessons from the global decline of amphibian populations. Ecology Letters, 5: 567-608 (2002).

[27] Pellet J., Conservation of a threatened European tree frog (Hyla arborea) metapopulation. Thèse de Doctorat ès sciences de la vie, UNIL, 98p (2005).

[28] Assémian N.E., Étude de la diversité de l'herpétofaune dans la zone de conservation de la biodiversité du barrage hydroélectrique de Soubré (Côte d'ivoire). Rapport d'étude d'impact environnemental, 7p (2017).

[29] Zug G.R., Amphibians and reptiles of the Outamba-Kilimi region, Sierra-Leone. J. Herpetol. Ass. Afr., 33 : 1-4 (1987). 
Habitat-Based Breeding Strategies of Female Hoplobatrachus occipitalis (Anura: Dicroglossidae) from Daloa Department, Midwest of Côte d'Ivoire

[30] Rödel M.O., Les communautés d'amphibiens dans le Parc National de Tai, Cote d'Ivoire. Les anoures comme bio-indicateurs de l'état des habitats. Rapport de Centre Suisse de la Recherche Scientifique, Abidjan: 108-113 (2000b).

[31] Channing A., Amphibian of Central and Southern Africa. Cornell University press, Ithaca, NY, 415p (2001).

[32] Prado C.A. and Haddad C.F.B., Size-fecundity relationships and reproductive investment in female frogs in the Pantanal, South-western Brazil. Herpetological Journal, vol. 15: 181-189 (2005).

[33] Lemckert F.L. and Shine R., Costs of reproduction in a population of the frog Crinia signifera (Anura: Myobatrachidae) from Southeastern Australia. Journal of Herpetology 27, 420-425 (1993).

[34] Lüddecke H., Variation and trade-off in reproductive output of the Andean frog Hyla labialis. Oecologia 130, 403-410 (2002).

Citation: ALIKO N'guessan Gustave, et al., "Habitat-Based Breeding Strategies of Female Hoplobatrachus occipitalis (Anura: Dicroglossidae) from Daloa Department, Midwest of Côte d'Ivoire", International Journal of Research Studies in Zoology, vol. 4, no. 3, p. 28-36, 2018. http://dx.doi.org/10.20431/2454-941X.0403005

Copyright: (C) 2018 Authors. This is an open-access article distributed under the terms of the Creative Commons Attribution License, which permits unrestricted use, distribution, and reproduction in any medium, provided the original author and source are credited. 